\title{
Klasifikasi Penyakit Tanaman Padi Menggunakan Model Deep Learning Efficientnet B3 Dengan Transfer Learning
}

\author{
Endang Anggiratih ${ }^{1 *}$, Sri Siswanti ${ }^{2)}$, Saly Kurnia Octaviani ${ }^{3)}$, Arumsari $^{4)}$ \\ 1,2) Program Studi Informatika, STMIK Sinar Nusantara Surakarta \\ 3) Program Studi D3-Sistem Informasi, STMIK Sinar Nusantara Surakarta \\ 4) Program Studi S1-Sistem Informasi, STMIK Sinar Nusantara Surakarta \\ ${ }^{1)}$ endanggiratih@ sinus.ac.id, ${ }^{2)}$ syswanty@ sinus.ac.id, ${ }^{3)}$ sally@ sinus.ac.id, ${ }^{4)}$ arumsari@ sinus.ac.id
}

\begin{abstract}
The level of rice productivity is influenced by several inhibiting factors, for example disease attack in rice plants. The slow and inappropriate treatment of rice plant can make the crop failure so that rice production and farmers' income decrease. The symptoms of rice disease are difficult to distinguish, especially in severe symptoms. Collaboration with other fields, especially computer science, is needed to classify diseases automatically so that the farmers can take action for plant treatment and the spread of disease can be controlled quickly. The classification of diseases based on images requires the best features/characteristics so that the disease can be classified. In this research, Deep Learning method, especially Convolutional Neural Network with EfficientNet B3 architecture, can extract features very well. In this research, the classification of brown spot and bacterial leaf disease by applying EfficientNet B3 with transfer learning reached $79.53 \%$ accuracy and 0.012 loss/error.
\end{abstract}

Keyword: Rice Plant Disease, Deep learning, EfficientNet B3

\section{PENDAHULUAN}

Sektor pertanian merupakan faktor yang sangat penting terkait ketahanan pangan. Jumlah produksi padi menjadi hal yang paling diperhatikan mengingat tanaman padi merupakan komoditas terbesar saat ini. Tingkat produktivitas padi dipengaruhi beberapa faktor penghambat salah satunya yaitu penyakit pada tanaman padi. Penanganan yang kurang cepat dan tidak tepat dapat mengakibatkan gagal panen sehingga produksi padi menjadi menurun serta penghasilan petani juga berkurang. Gejala-gejala penyakit padi sulit dibedakan, khususnya gejala tersebut sudah lanjut (Lestari, 2019). Negara-negara yang menjadikan padi sebagai bahan makanan pokoknya, terutama Indonesia sedang gencar melakukan inovasi untuk mengatasi permasalahan yang disebabkan oleh penyakit padi agar ketersediaan bahan pokok menjadi stabil. Inovasi dilakukan dengan kerjasama di berbagai bidang, salah satunya di bidang ilmu komputer. Kolaborasi bidang pertanian dengan ilmu komputer yaitu berkaitan dengan pengenalan pola yang memanfaatkan sistem komputer vision yang dapat mengidentifikasi penyakit pada tanaman padi, sehingga petani menjadi mudah dalam mengambil tindakan (Haris, 2020).

Salah satu tahapan identifikasi penyakit padi dengan melalui citra yaitu ekstraksi fitur yang digunakan untuk mendapatkan informasi mengenai ciri-ciri penyakit padi berdasarkan citra daun. Proses menyeleksi fitur yang terbaik memerlukan waktu yang lama dan menghasilkan error yang cukup tinggi meskipun dengan jumlah dataset yang sedikit. (Murniyasih et al., 2020). Penggunaan machine learning khususnya deep learning biasanya untuk kasus dengan penyeleksian fitur yang kompleks dan dapat dilakukan dalam jumlah dataset yang besar, sehingga dapat meningkatkan performa dalam menyeleksi fitur dengan waktu yang cukup cepat (Rahman et al., 2020). Metode deep learning yang sering digunakan yaitu convolutional neural network (CNN), dimana dapat mengekstraksi fitur secara otomatis dan lebih efisien sehingga dapat menghasilkan klasifikasi yang tepat pula. 
Efficientnet merupakan salah satu arsitektur CNN yang dapat memprediksi dan mengklasifikasi objek secara akurat dan dapat diaplikasikan ke peralatan mobile yang memiliki komputasi terbatas (Duong et al., 2020). Sehingga pada penelitian ini menggunakan arsitektur Efficientnet B3, dengan harapan dapat mengklasifikasi penyakit padi dengan akurat dan secara otomatis, agar petani dapat mengetahui penyakit padi dengan mudah, sehingga dalam mengambil tindakan selanjutnya dapat dilakukan secara tepat dan penyebaran penyakit dapat dikendalikan.

\section{TINJAUAN PUSTAKA}

Penelitian yang mengidentifikasi 10 jenis penyakit tanaman padi menggunakan metode Convolutional Neural Network (CNN) yang terdiri dari 3 lapisan konvolusi, 3 lapisan pooling, dan 1 lapisan softmax. Pada prapemrosesan citra menggunakan metode PCA (Principal Component Analysis) untuk mendapatkan fitur pelatihan dan pengujian. Penelitian ini menghasilkan akurasi $95 \%$ dengan membandingkan metode lainnya seperti Backpropagation, Support Vector Machine, dan Particle Swarm Optimazation. Dataset yang digunakan sebanyak 500 citra daun padi yang berasal dari akademi Heilongjiang Cina, dataset tersebut terdiri dari 10 kelas yaitu Blast, False Smut, Brown Spot, Bakanae, Sheath Blight, Sheath Rot, Bacterial Leaf Blight, Bacterial Sheath Rot, Seeding Blight, dan Bacterial Wilt (Lu et al., 2017).

Penelitian yang memanfaatkan dataset berjumlah sedikit dalam mengklasifikasikan penyakit tanaman padi menggunakan $\mathrm{CNN}$ dengan transfer learning, yang berfungsi untuk membangun model pembelajarannya. Arsitektur CNN yang digunakan yaitu VGG-16 yang menghasilkan akurasi $92,46 \%$ dengan membedakan penyakit yang terdiri dari 4 kelas, diantaranya Leaf Blast, Leaf Blight, Brown Spot, dan Healthy. Proses pelatihan untuk model dataset menggunakan perbandingan $70 \%$ untuk dataset pelatihan yang berjumlah 1509, sedangkan 30\% untuk data pengujian yang berjumlah 647 (Ghosal \& Sarkar, 2020).

Transfer learning juga digunakan pada penelitian Deep Convolutional Neural Network dengan proses klasifikasi dibagi menjadi 2 tahap yaitu tahap ekstraktor fitur dilakukan menggunakan pre-trained deep $\mathrm{CNN}$ dengan arsitektur Alexnet dan tahap klasifikasi menggunakan metode support vector machine, menghasilkan akurasi 91,3\%. Dataset berjumlah 619 citra yang terbagi menjadi 4 kelas, diantaranya blast, bacterial leaf blight, sheath blight, dan healthy. Proses pelatihannya dengan menganalisis perbandingan jumlah dataset, terdapat 3 perbandingan diantaranya perbandingan ke-1 yaitu $60 \%$ data latih dan $40 \%$ data uji. Perbandingan ke-2 yaitu $70 \%$ data latih dan $30 \%$ data uji, perbandingan yang terakhir yaitu $80 \%$ data latih dan $20 \%$ data uji. Akurasi tertinggi diperoleh dari perbandingan ke-3. Pembagian dataset tersebut dilakukan karena ketersediaan dataset yang sedikit. (Shrivastava et al., 2019).

\section{METODE PENELITIAN}

\subsection{Analisis Kebutuhan}

Analisis kebutuhan merupakan batasan dari masukan, proses, dan keluaran yang terdiri dari:

1. Dataset citra: menggunakan dataset yang telah disediakan oleh (Prajapati et al., 2017), terdiri 857 citra penyakit padi yang terdiri dari brown spot (bercak coklat) dan bacterial leaf (hawar daun). Citra diambil menggunakan kamera digital SLR NIKON D90 di desa Sherta, India. Dimensi keseluruhan citra 2848x4288, dengan latar belakang berwarna putih dan pengambilan gambar dilakukan saat siang hari.

2. Masukan proses: dataset terbagi menjadi 2 kelas yaitu kelas brown spot dan kelas bacterial leaf. Citra tersebut mempunyai resolusi yang berbeda-beda sehingga dilakukan pengubahan resolusi menjadi 300x300 untuk arsitektur Efficientnet B3 
dan 224x224 untuk arsitektur Mobilenet V3. Dataset terbagi menjadi 3 bagian dengan perbandingan 60 untuk data latih, 20 untuk data validasi, dan 20 untuk data uji.

3. Keluaran proses: klasifikasi terhadap penyakit brown spot dan bacterial leaf.

\subsection{Perancangan Penelitian}

Tahapan-tahapan yang dilakukan terbagi menjadi 2 yaitu tahap pertama adalah pelatihan yang terdiri dari input citra, pembagian dataset, ekstraksi ciri, dan model jaringan masing-masing kelas. Tahap kedua merupakan tahap pengujian yang berupa klasifikasi penyakit padi.

\subsection{Tahap Pelatihan Arsitektur}

Tahap pelatihan disebut juga dengan proses pembelajaran pada arsitektur berdasarkan fitur yang dimiliki masing-masing kelas. Tahap ini terdiri dari pembagian dataset menjadi data train, data validasi, dan data test. Pada proses ekstraksi fitur yang digunakan hanya data train dan data validasi yang menghasilkan dua kelas. Berikut tahapan pelatihan arsitektur ditampilkan pada Gambar 1.

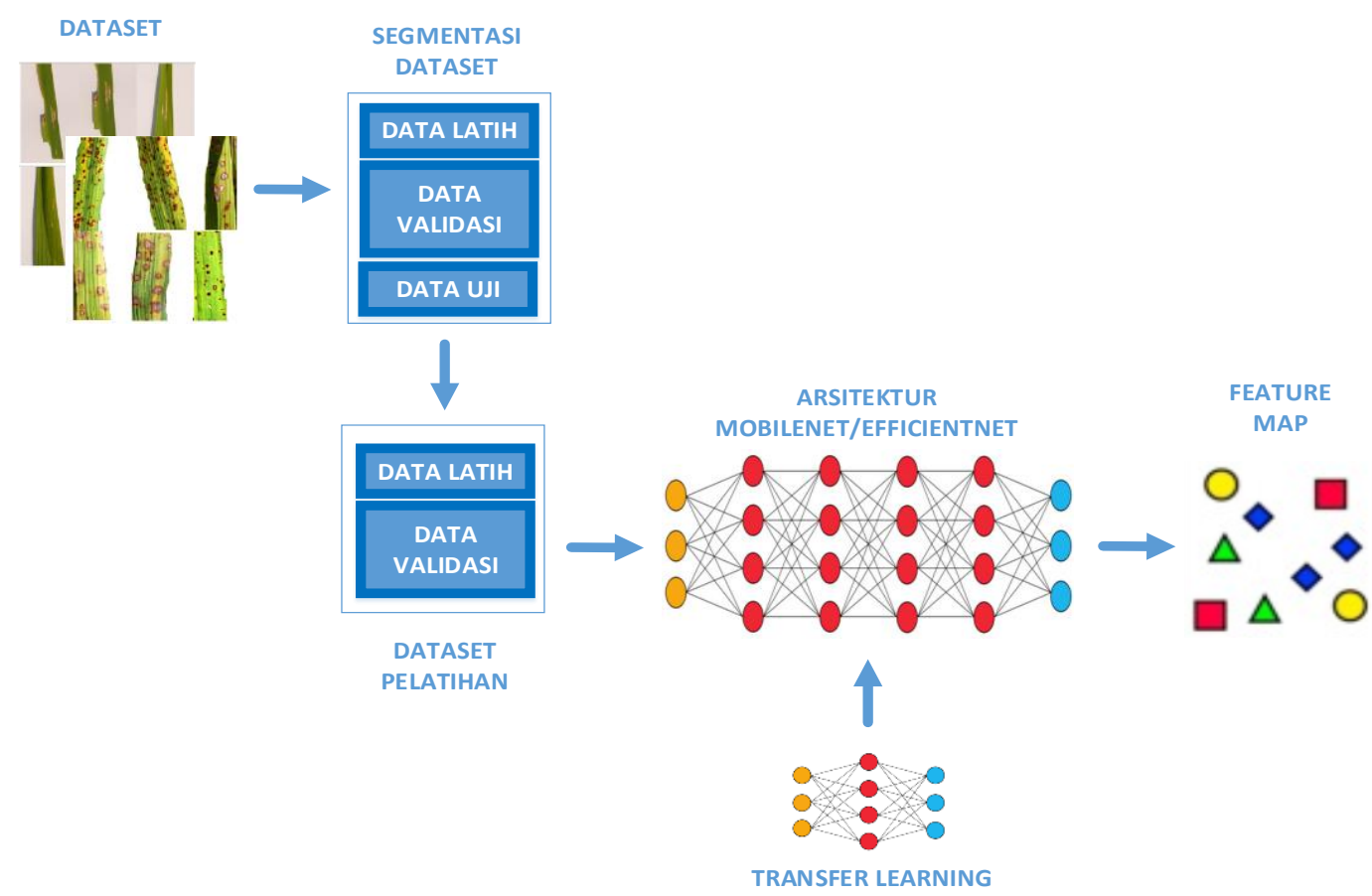

Gambar 1. Pelatihan Arsitektur

Dataset yang telah terbagi selanjutnya akan diekstrak cirinya/fiturnya kedalam jaringan Mobilenet V3 atau Efficientnet B3 berdasarkan nilai parameter arsitektur yang telah dilatih menggunakan dataset lain yaitu ImageNet yang menghasilkan nilai transfer learning. Penggunaan transfer learning bertujuan agar pelatihan menggunakan dataset yang berbeda menjadi lebih efektif dan efisien. Hasil dari pelatihan berupa feature map yang merupakan fitur/ciri terbaik dari masing-masing kelas.

\subsection{Tahap Pengujian}

Tahap pengujian bertujuan untuk mencari nilai akurasi/ketepatan dalam mengklasifikasi kelas terhadap data test yang belum pernah dipelajari sebelumnya. 
Performa suatu arsitektur dinilai dari akurasi yang dihasilkan pada data test. Tahapan pengujian dapat dilihat pada Gambar 2.

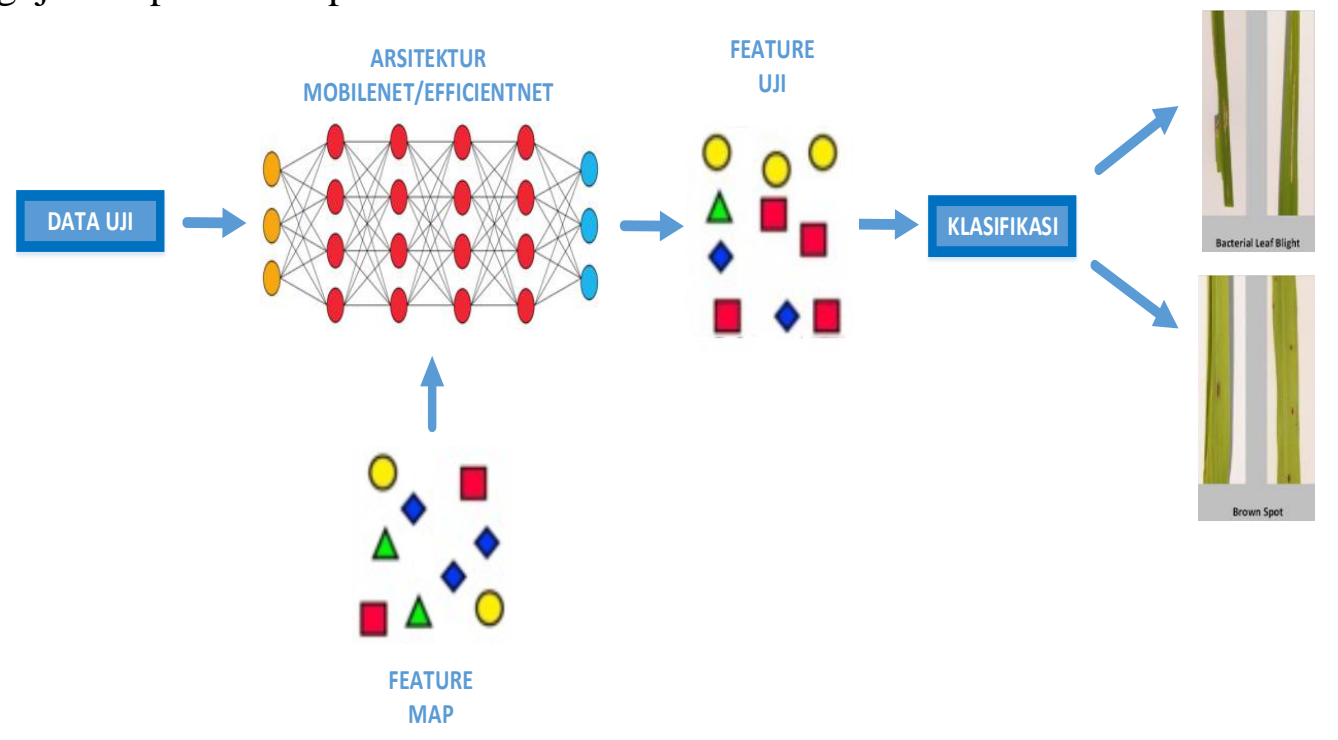

Gambar 2. Pengujian

Proses pengujian mengekstrak fitur dari data test dan dibandingkan dengan feature map yang telah diperoleh dari tahap pelatihan arsitektur, kemudian akan menghasilkan feature uji yang akan diklasifikasikan kedalam masing-masing kelas.

\section{HASIL DAN PEMBAHASAN}

Sistem diimplementasikan menggunakan beberapa peralatan penelitian, berupa:

- Perangkat lunak: sistem operasi Windows 10 Pro - 64 bit, JetBrains PyCharm Community Edition 2020.2.1x64 dengan Bahasa pemrograman Python serta library Keras dan Tensorflow yang berfungsi sebagai pembangun struktur citra digital dan menyediakan prosedur serta fungsi yang dibutuhkan serta arsitektur jaringan deep learning.

- Perangkat keras: satu unit komputer dengan spesifikasi Intel ${ }^{\circledR} \mathrm{Core}^{\mathrm{TM}} \mathrm{i5}-9400 \mathrm{~F}$, CPU@2.90GHz, 8192MB RAM, Harddisk 2TB, dan resolusi monitor 1280x1024

\subsection{Hasil Tahap Pelatihan Arsitektur}

Sebelum melakukan proses pelatihan, dataset disegmentasi menjadi 3 bagian yaitu data train/latih, data validasi, dan data test/uji dimana perbandingannya 60:20:20. Data train sebanyak 258 citra untuk kelas penyakit brown spot serta 255 citra untuk kelas penyakit bacterial leaf dan data validasi sebanyak 87 citra untuk kelas penyakit brown spot dan 86 citra untuk kelas penyakit bacterial leaf yang digunakan saat proses pelatihan. Resolusi citra pada data train diubah terlebih sesuai arsitektur yang akan dibandingkan, untuk arsitektur Mobilenet V3 resolusi diubah menjadi 224x224 piksel, sedangkan arsitektur Efficientnet B3 resolusi diubah menjadi $300 \times 300$ piksel. Data validasi digunakan untuk mengkonfirmasikan melalui pengujian berdasarkan dataset yang telah dipelajari pada tahap pelatihan. Dataset untuk pelatihan terbagi menjadi 2 kelas yaitu kelas penyakit brown spot dan kelas penyakit bacterial leaf, seperti yang ditunjukkan pada Gambar 1 dan Gambar 2. 


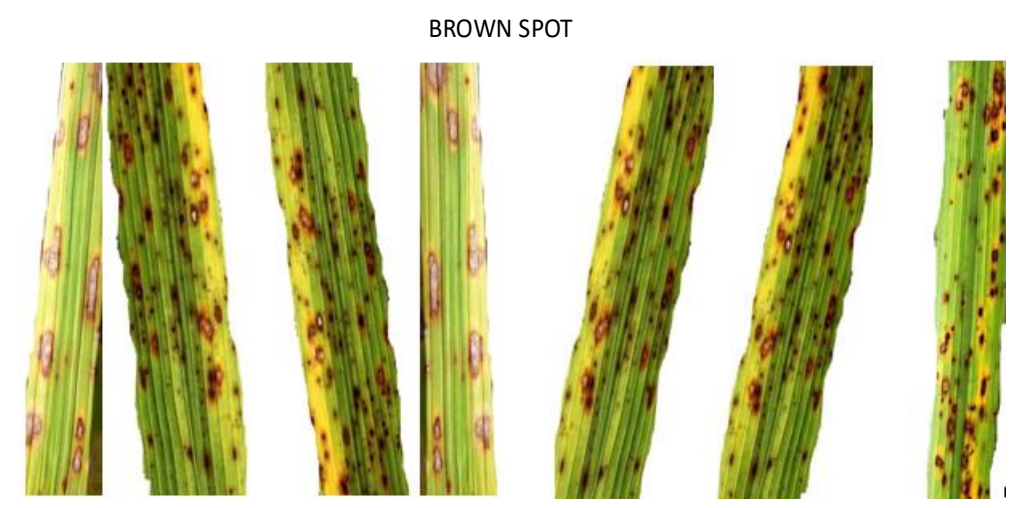

Gambar 1. Penyakit Brown Spot Bacterial LeAF

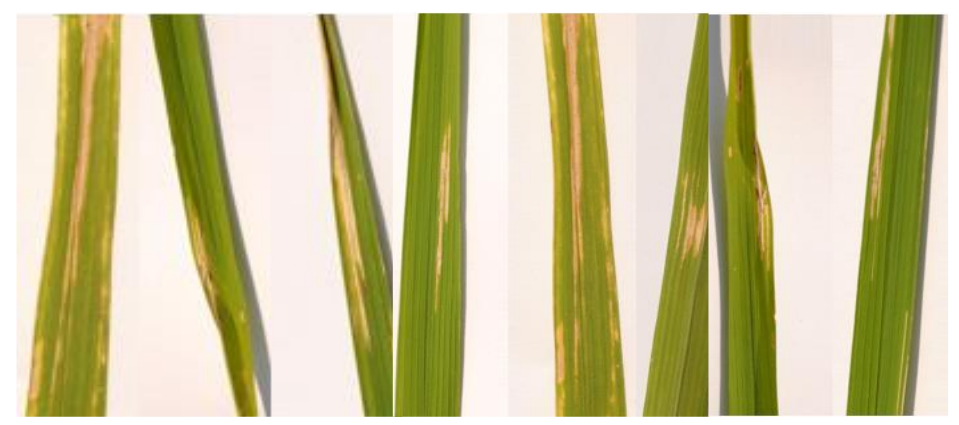

Gambar 2. Penyakit Bacterial Leaf

Proses pelatihan arsitektur menggunakan nilai parameter yang telah dilatih yang berasal dari transfer learning dengan membandingkan arsitektur Mobilenet V3 dengan Efficientnet B3 yang bertujuan untuk mengetahui tingkat akurasi dari kedua arsitektur tersebut. Pelatihan menggunakan arsitektur Mobilenet V3 yang memiliki spesifikasi terdiri dari 4 convolution layer, 15 bottleneck layer, dan 1 pooling layer, menghasilkan 5,4M parameter. Spesifikasi arsitektur Mobilenet V3 ditunjukkan pada Tabel 1 dan Gambar 3.

Tabel 1. Spesifikasi arsitektur Mobilenet V3 (Howard et al., 2019)

\begin{tabular}{|c|c|c|c|c|c|c|}
\hline Input & Layer & Expensive size & Out & SE Block & NonLinear & Stride \\
\hline $224^{2} \times 3$ & Conv2d & - & 16 & - & HS & 2 \\
\hline $112^{2} \times 16$ & Bneck, 3 × 3 & 16 & 16 & - & $\mathrm{RE}$ & 1 \\
\hline $112^{2} \times 16$ & Bneck, $3 \times 3$ & 64 & 24 & - & RE & 2 \\
\hline $56^{2} \times 24$ & Bneck, 3 × 3 & 72 & 24 & - & $\mathrm{RE}$ & 1 \\
\hline $56^{2} \times 24$ & Bneck, $5 \times 5$ & 72 & 40 & $\sqrt{ }$ & $\mathrm{RE}$ & 2 \\
\hline $28^{2} \times 40$ & Bneck, $5 \times 5$ & 120 & 40 & $\sqrt{ }$ & $\mathrm{RE}$ & 1 \\
\hline $28^{2} \times 40$ & Bneck, $5 \times 5$ & 120 & 40 & $\sqrt{ }$ & $\mathrm{RE}$ & 1 \\
\hline $28^{2} \times 40$ & Bneck, 3 × 3 & 240 & 80 & - & $\mathrm{HS}$ & 2 \\
\hline $14^{2} \times 80$ & Bneck, 3 × 3 & 200 & 80 & - & HS & 1 \\
\hline $14^{2} \times 80$ & Bneck, 3 x 3 & 184 & 80 & - & $\mathrm{HS}$ & 1 \\
\hline $14^{2} \times 80$ & Bneck, 3 × 3 & 184 & 80 & - & HS & 1 \\
\hline $14^{2} \times 80$ & Bneck, $3 \times 3$ & 480 & 112 & $\sqrt{ }$ & HS & 1 \\
\hline $14^{2} \times 80$ & Bneck, 3 × 3 & 672 & 112 & $\sqrt{ }$ & HS & 1 \\
\hline $14^{2} \times 80$ & Bneck, $5 \times 5$ & 672 & 160 & $\sqrt{ }$ & HS & 2 \\
\hline $7^{2} \times 160$ & Bneck, $5 \times 5$ & 960 & 160 & $\sqrt{ }$ & $\mathrm{HS}$ & 1 \\
\hline $7^{2} \times 160$ & Bneck, $5 \times 5$ & 960 & 160 & $\sqrt{ }$ & HS & 1 \\
\hline $7^{2} \times 160$ & Conv2d, $1 \times 1$ & - & & - & HS & 1 \\
\hline $7^{2} \times 160$ & Pool, $7 \times 7$ & - & & - & - & 1 \\
\hline $1^{2} \times 960$ & Conv2d, $1 \times 1, \mathrm{NBN}$ & - & & - & HS & 1 \\
\hline $1^{2} \times 1280$ & Conv2d, $1 \times 1, \mathrm{NBN}$ & - & & - & - & 1 \\
\hline
\end{tabular}




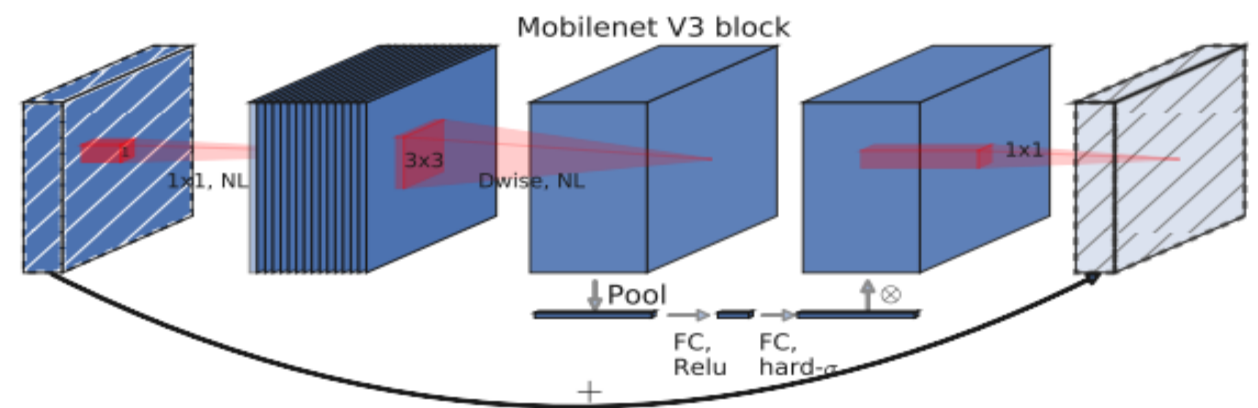

Gambar 3. Arsitektur Mobilenet V3 (Howard et al., 2019)

Sedangkan pelatihan menggunakan arsitektur Efficientnet B3 mempunyai spesifikasi yang terdiri dari 2 convolution layer, 7 mobile bottleneck convolution layer, 1 pooling layer, dan 1 fully connected layer, menghasilkan $12 \mathrm{M}$ parameter. Struktur layer Efficientnet B3 pada dasarnya menggunakan struktur layer Efficientnet B0 hanya saja yang berbeda adalah jumlah layer-nya. Spesifikasi Efficientnet B0 ditunjukkan pada Tabel 2.

Tabel 2. Spesifikasi arsitektur Efficientnet (Tan \& Le, 2019)

\begin{tabular}{|c|c|c|}
\hline Layer & Resolusi & Channels \\
\hline Conv3x3 & $224 \times 224$ & 32 \\
\hline MBConv1, k3x3 & $112 \times 112$ & 16 \\
\hline MBConv6, k3x3 & $112 \times 112$ & 24 \\
\hline MBConv6, k5x5 & $56 \times 56$ & 40 \\
\hline MBConv6, k5x5 & $28 \times 28$ & 80 \\
\hline MBConv6, k5x5 & $14 \times 14$ & 112 \\
\hline MBConv6, k5x5 & $14 \times 14$ & 192 \\
\hline MBConv6, k3x3 & $7 \times 7$ & 320 \\
\hline Conv3x3 \& Pooling \& FC & $7 \times 7$ & 1280 \\
\hline
\end{tabular}

Proses pelatihan arsitektur digunakan untuk menghasilkan feature map terbaik berdasarkan data train. Hasil pelatihan terhadap arsitektur menunjukkan akurasi pelatihan yang berbeda-beda untuk beberapa epoch. Penilaian akurasi menggunakan metode Hold Out yaitu pembagian dataset menjadi beberapa porsi, dalam penelitian ini akurasi pelatihan dengan akurasi pengujian menggunakan prosentase $60 / 20$, yang artinya $60 \%$ sebagai dataset train dan $20 \%$ untuk dataset test. Dilakukan perbandingan antara arsitektur Efficientnet B3 dengan arsitektur Mobilenet V3 untuk mengetahui tingkat akurasi dikedua arsitektur tersebut. Hasil pelatihan ditunjukkan pada Tabel 3, dan grafiknya ditunjukkan pada Gambar 4.

Tabel 3. Perbandingan akurasi training/pelatihan Mobilenet V3 dan Efficientnet B3

\begin{tabular}{|c|c|c|}
\hline \multirow{2}{*}{ Epoch } & \multicolumn{2}{|c|}{ Akurasi Training } \\
\cline { 2 - 3 } & Mobilenet V3 & Efficientnet B3 \\
\hline 50 & $54 \%$ & $55 \%$ \\
\hline 100 & $56 \%$ & $64 \%$ \\
\hline 150 & $57 \%$ & $56 \%$ \\
\hline 200 & $57 \%$ & $93 \%$ \\
\hline 250 & $57 \%$ & $98 \%$ \\
\hline 300 & $57 \%$ & $98 \%$ \\
\hline 350 & $57 \%$ & $99 \%$ \\
\hline 400 & $57 \%$ & $99 \%$ \\
\hline
\end{tabular}




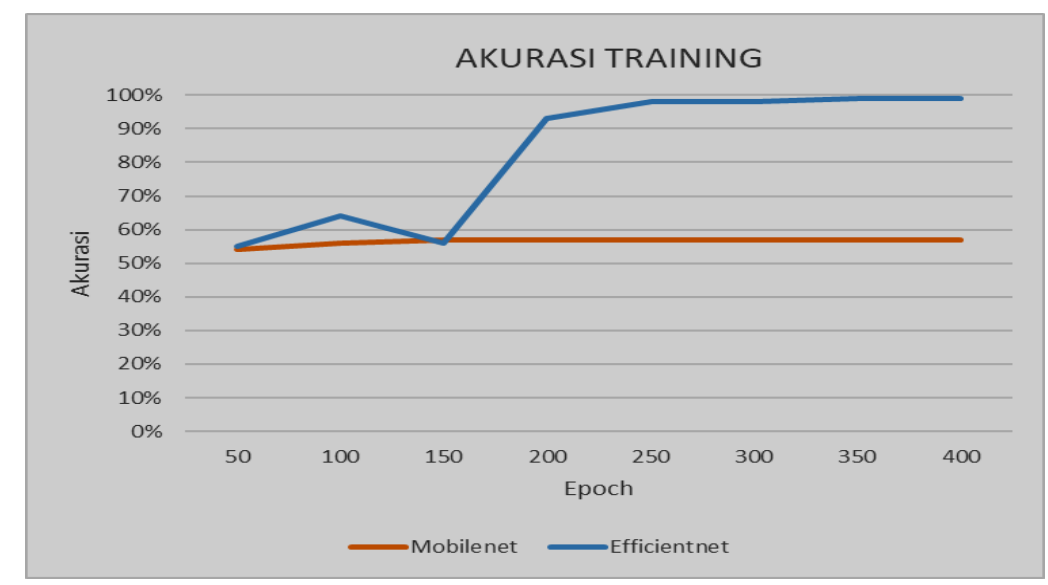

Gambar 4. Perbandingan akurasi pelatihan/training Mobilenet V3 dan Efficientnet B3

Perbandingan Loss juga dilakukan antara Mobilenet V3 dan Efficientnet B3 untuk beberapa epoch. Perbandingan loss ditunjukkan pada Tabel 4 dan grafiknya ditunjukkan pada Gambar 5. Loss terendah pada Mobilenet V3 yaitu 0,007 saat epoch mencapai 300, sedangkan pada Efficientnet B3 loss terendah saat mencapai epoch ke350 yaitu senilai 0,012 . Nilai loss berbanding terbalik dengan nilai akurasi pelatihan makin tinggi nilai akurasi maka makin rendah nilai loss yang dihasilkan.

Tabel 4. Perbandingan loss training/pelatihan Mobilenet V3 dan Efficientnet B3

\begin{tabular}{|c|c|c|}
\hline \multirow{2}{*}{ Epoch } & \multicolumn{2}{|c|}{ Loss Training } \\
\cline { 2 - 3 } & Mobilenet V3 & Efficientnet B3 \\
\hline 50 & 0,249 & 0,684 \\
\hline 100 & 0,091 & 0,599 \\
\hline 150 & 0,049 & 0,666 \\
\hline 200 & 0,042 & 0,19 \\
\hline 250 & 0,043 & 0,046 \\
\hline 300 & 0,007 & 0,042 \\
\hline 350 & 0,008 & 0,012 \\
\hline 400 & 0,071 & 0,038 \\
\hline
\end{tabular}

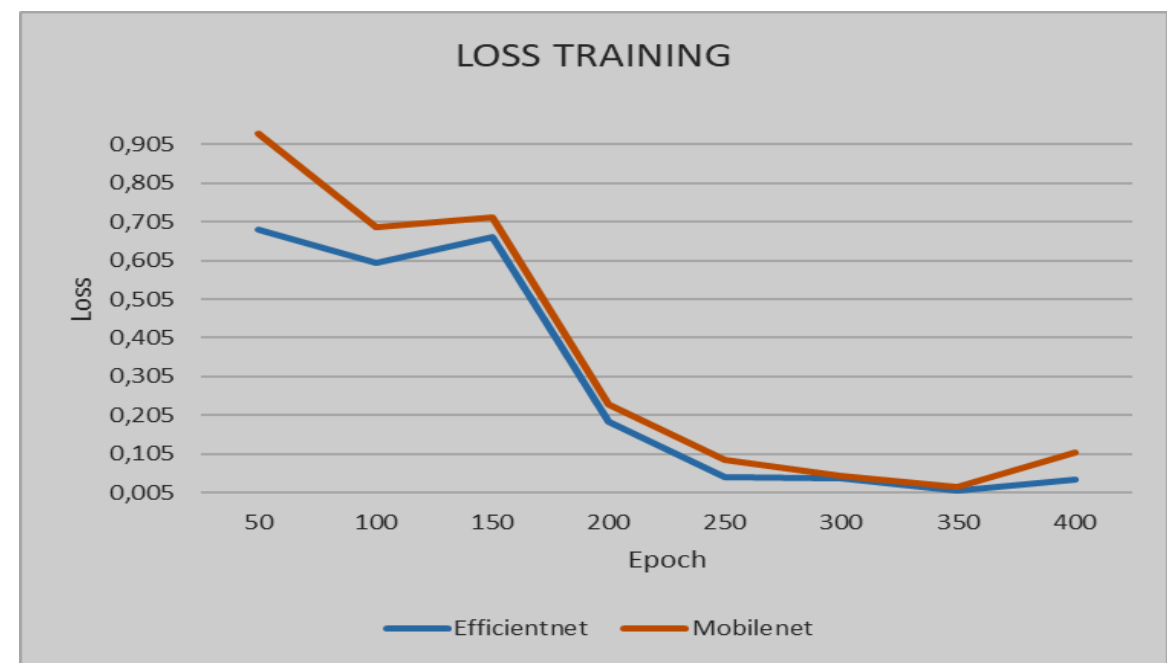

Gambar 5. Perbandingan loss pelatihan/training Mobilenet V3 dan Efficientnet B3 


\subsection{Hasil Tahap Pengujian}

Pengujian pada tahap klasifikasi menggunakan data test yang sudah di segmentasi pada saat proses pelatihan sebanyak 85 citra untuk kelas penyakit brown spot dan 86 citra kelas penyakit bacterial leaf. Proses ini mengklasifikasikan citra berdasarkan fitur terbaik yang diperoleh dari hasil pelatihan. Pengujian ini ditunjukkan pada Tabel 5.

Tabel 5. Perbandingan akurasi testing/pengujian Mobilenet V3 dan Efficientnet B3

\begin{tabular}{|c|c|c|}
\hline \multirow{2}{*}{ Epoch } & \multicolumn{2}{|c|}{ Akurasi Testing } \\
\cline { 2 - 3 } & Mobilenet V3 & Efficientnet B3 \\
\hline 50 & $50,92 \%$ & $38,60 \%$ \\
\hline 100 & $51,07 \%$ & $49,71 \%$ \\
\hline 150 & $54,32 \%$ & $56,14 \%$ \\
\hline 200 & $52,48 \%$ & $63,74 \%$ \\
\hline 250 & $52,18 \%$ & $74,27 \%$ \\
\hline 300 & $\mathbf{5 4 , 3 2 \%}$ & $71,35 \%$ \\
\hline 350 & $52,62 \%$ & $\mathbf{7 9 , 5 3 \%}$ \\
\hline 400 & $51,52 \%$ & $76,02 \%$ \\
\hline
\end{tabular}

Proses pengujian terhadap dataset test/uji dilakukan secara acak, pengujian ini ditunjukkan pada Tabel 5 untuk klasifikasi penyakit brown spot dan bacterial leaf mendapat akurasi teritinggi pada arsitektur Efficientnet yaitu sebesar 79,53\% pada epoch ke-350, dibandingkan dengan arsitektur Mobilenet V3 memperoleh akurasi lebih rendah yaitu sebesar 54,32\% pada epoch ke-300. Penambahan epoch telah dilakukan namun menghasilkan akurasi yang makin menurun, ini menunjukkan bahwa arsitektur mengalami overfitting saat epoch bertambah lebih dari 350 untuk Efficientnet B3 dan lebih dari 300 untuk Mobilenet V3.

\section{KESIMPULAN DAN SARAN}

\subsection{Kesimpulan}

Fitur/ciri terbaik diperoleh dari arsitektur Efficientnet B3 yang ditunjukkan oleh tingginya akurasi pelatihan dan rendahnya loss pelatihan yaitu 99\% dan 0,012, namun akurasi yang lebih rendah dihasilkan oleh arsitektur Mobilenet V3 yaitu 57\% dengan loss 0,007. Kedua arsitektur tersebut menggunakan transfer learning untuk model pelatihannya Berdasarkan hasil akurasi pelatihan kedua arsitektur maka dapat menentukan akurasi pengujian dengan menggunakan data test yang belum dipelajari sebelumnya. Akurasi pengujian untuk klasifikasi penyakit brown spot dan bacterial leaf yang dihasilkan pada arsitektur Efficientnet B3 lebih tinggi dibandingkan dengan arsitektur Mobilenet V3 yaitu 79,53\%. Penggunaan data test secara acak antara kedua kelas penyakit. Kesimpulannya yaitu klasifikasi penyakit padi berdasarkan fitur yang diperoleh dari citra daun dapat diklasifikasikan dengan baik oleh Efficientnet B3.

\subsection{Saran}

Pengembangan klasifikasi ini masih memiliki banyak kelemahan dan keterbatasan. Saran yang dapat diberikan yaitu perlu dilakukan penelitian lebih lanjut mengenai arsitektur Efficientnet B3 tanpa menggunakan transfer learning dan diperlukan modifikasi dalam struktur arsitekturnya. 


\section{DAFTAR PUSTAKA}

Duong, L. T., Nguyen, P. T., Sipio, C. Di, \& Ruscio, D. Di. (2020). Automated fruit recognition using E ffi cientNet and MixNet. Computers and Electronics in Agriculture, 171(January), 105326. https://doi.org/10.1016/j.compag.2020.105326

Ghosal, S., \& Sarkar, K. (2020). Rice Leaf Diseases Classification Using CNN with Transfer Learning. 2020 IEEE Calcutta Conference, CALCON 2020 - Proceedings, 230-236. https://doi.org/10.1109/CALCON49167.2020.9106423

Haris, N. A. (2020). Kombinasi Ciri Bentuk dan Ciri Tekstur Untuk Identifikasi Penyakit Pada Tanaman Padi. JATISI (Jurnal Teknik Informatika Dan Sistem Informasi), 7(2), 237-250. https://doi.org/10.35957/jatisi.v7i2.239

Howard, A., Sandler, M., Chen, B., Wang, W., Chen, L. C., Tan, M., Chu, G., Vasudevan, V., Zhu, Y., Pang, R., Le, Q., \& Adam, H. (2019). Searching for mobileNetV3. Proceedings of the IEEE International Conference on Computer Vision, 2019-Octob, 1314-1324. https://doi.org/10.1109/ICCV.2019.00140

Lestari, T. A. (2019). Pengamatan Penyakit-Penyakit Tanaman Sistem Jajar Legowo Observation Of Paddy Diseases In The Vilage Of Sako Rambutan Sub-District Banyuasin With The Jajar Legowo System.

Lu, Y., Yi, S., Zeng, N., Liu, Y., \& Zhang, Y. (2017). Identification of rice diseases using deep convolutional neural networks. Neurocomputing, 267, 378-384. https://doi.org/10.1016/j.neucom.2017.06.023

Murniyasih, E., Suryani, L., Sorong, S. P., \& Sorong, S. P. (2020). Penerapan Metode Learning Vector Quantization. 6(1).

Prajapati, H. B., Shah, J., Technologies, D., \& Dabhi, V. (2017). Publication Details: Detection and Classification of Rice Plant Diseases. August 2018. https://doi.org/10.3233/IDT-170301

Rahman, C. R., Arko, P. S., Ali, M. E., Iqbal Khan, M. A., Apon, S. H., Nowrin, F., \& Wasif, A. (2020). Identification and recognition of rice diseases and pests using convolutional neural networks. Biosystems Engineering, 194, 112-120. https://doi.org/10.1016/j.biosystemseng.2020.03.020

Shrivastava, V. K., Pradhan, M. K., Minz, S., \& Thakur, M. P. (2019). Rice plant disease classification using transfer learning of deep convolution neural network. International Archives of the Photogrammetry, Remote Sensing and Spatial Information Sciences - ISPRS Archives, 42(3/W6), 631-635. https://doi.org/10.5194/isprs-archives-XLII-3-W6-631-2019

Tan, M., \& Le, Q. V. (2019). EfficientNet: Rethinking model scaling for convolutional neural networks. 36th International Conference on Machine Learning, ICML 2019, 2019-June, 10691-10700. 